\title{
Somewhere between Jim Crow \& Post-Racialism: Reflections on the Racial Divide in America Today
}

\section{Citation}

Bobo, Lawrence D. 2011. Somewhere between Jim Crow \& Post-Racialism: Reflections on the Racial Divide in America Today. Daedalus 140(2): 11-36.

\section{Published Version}

doi:10.1162/DAED_a_00091

\section{Permanent link}

http://nrs.harvard.edu/urn-3:HUL.InstRepos:11499002

\section{Terms of Use}

This article was downloaded from Harvard University's DASH repository, and is made available under the terms and conditions applicable to Open Access Policy Articles, as set forth at http:// nrs.harvard.edu/urn-3:HUL.InstRepos:dash.current.terms-of-use\#OAP

\section{Share Your Story}

The Harvard community has made this article openly available.

Please share how this access benefits you. Submit a story.

Accessibility 
Somewhere Between Jim Crow and Post-Racialism:

\section{Reflections on the Racial Divide in America Today}

Lawrence D. Bobo, Department of Sociology,

Harvard University

16 March 2011 


\section{Somewhere Between Jim Crow and Post-Racialism: Reflections on the Racial Divide in America Today}

In assessing the results of the Negro revolution so far, it can be concluded that Negroes have established a foothold, no more. We have written a Declaration of Independence, itself an accomplishment, but the effort to transform the words into a life experience still lies ahead.

- Martin Luther King Jr., Where Do We Go From Here?: Chaos or Community?, 1968, p. 19.

By the middle of the twentieth century, the color line was as well defined and as firmly entrenched as any institution in the land. Afterall, it was older than most institutions, including the federal government itself. More important, it informed the content and shaped the lives of those institutions and the people who lived under them"

- John Hope Franklin, The Color Line: Legacy for the $21^{\text {st }}$ Century, 1993, p. 36.

This is where we are right now. It's a racial stalemate we've been stuck in for years. Contrary to the claims of some of my critics, black and white, I have never been so naïve as to believe that we can get beyond our racial divisions in a single election cycle, or with a single candidacy - particularly a candidacy as imperfect as my own.

- Barack H. Obama, “A More Perfect Union," Philadelphia, May 18, 2008.

\section{INTRODUCTION}

The year 1965 marked an important inflection point in the struggle for racial justice in the United States. That inflection point underscored two fundamental points about race in America. First, that racial inequality and division was not only a Southern problem attached to Jim Crow segregation. Second, that the nature of those inequalities and divisions was not merely a matter of formal civil status and law, but also of deeply etched economic arrangements, social and political conditions, and cultural outlooks and practices. Viewed in full, the racial divide was a challenge of truly national reach, and multi-layered complexity and depth. As 
such, the achievement of basic citizenships rights in the South was a pivotal but far from exhaustive stage of the struggle.

The positive trend of the times revolved around the achievement of voting rights. March $7^{\text {th }}$ of that year, now known as "Bloody Sunday," saw the attack on several hundred peaceful civil rights protestors by police and state troopers at the Edmund Pettis bridge in Selma, Alabama. The subsequent March from Selma-toMontgomery, participated in by tens of thousands, and other protest actions, provided the pressure that finally compelled Congress to pass the Voting Rights Act of 1965. A triumphant Reverend Martin Luther King Jr. and other activists attended the signing in Washington, DC on August $6^{\text {th }}$ of that year. It was, simply put, a moment of great triumph for civil rights.

The long march to freedom seemed to be at it's apex, inspiring talk of an era of "Second Reconstruction". A decade earlier, of course, the U.S. Supreme Court in the historic 1954 Brown v. Board of Education decision had repudiated the "separate but equal" doctrine. Subsequently, a major civil rights movement victory had been achieved with the passage of the Civil Rights Act of 1964, which forbade discrimination in employment and in most public places. With voting rights now protected as well, and the federal government authorized to directly intervene to assure those rights, one might have expected 1965 to stand as a moment of shimmering and untarnished civil rights progress. Yet, the mood of optimism and triumph did not last for very long.

The negative trend of the times was epitomized by deep and explosive inequalities and resentments of race smoldering in many Northern, urban ghettoes. 
The extent to which the "race problem" was not just a Southern problem of civil rights, but a national problem of inequality woven deep into our economic and cultural fabric would quickly be laid bare following the passage of the VRA. Scarcely five days after then President Johnson signed the bill into law the Los Angeles community of Watts erupted into flames. Quelling the disorder, which raged for roughly six days, ultimately required the mobilization of the National Guard and nearly 15,000 troops. When disorder finally subsided, 34 people had lost their lives, more than 1,000 people had been injured, well over 3,000 people arrested, and approximately $\$ 35$ million in property damage had been done. Subsequent studies and reports revealed patterns of police abuse, myriad forms of economic, housing, and social discrimination, political marginalization, and intense poverty as contributing to the mix of conditions that led to the riots.

It was thus more than fitting that in 1965 Daedalus committed two issues to examining the conditions of "the Negro American." The essays were wide-ranging. The topics addressed spanned questions of power, demographic change, economic conditions, politics and civil status, religion and the church, family and community dynamics, as well as group identity, racial attitudes, and the future of race relations. Scholars from most social scientific fields, including anthropology, economics, history, law, political science, psychology, and sociology contributed to the volumes. No single theme or message dominated these essays. Instead, the volumes wrestled with the multi-dimensional and complex patterning of a rapidly changing terrain of race. 
Some critical observations stand out from two of those earlier essays, which have been amplified and made center pieces of much subsequent social science scholarship. Sociologist and anthropologist St. Clair Drake drew a critical distinction between what he termed primary victimization and indirect victimization. Primary victimization involved overt discrimination in the labor market that imposed a sort of job ceiling on the economic opportunities available to blacks and housing discrimination and segregation that relegated blacks into racially distinct urban ghettoes. Indirect or secondary victimization involved the multidimensional and cumulative disadvantages that were the consequence of the primary victimization. These included poorer schooling, poor health, greater exposure to disorder and crime, etc. In a related vein, sociologist Daniel Patrick Moynihan stressed the central importance of employment prospects in the wake of the civil rights victories securing the basic citizenship rights of African Americans. Both Drake and Moynihan expressed concern about a black class structure where there were signs of large and growing economically marginalized segment of the black community. Drake went so far as to declare: "If Negroes are not to become a permanent lumpen-proletariat within American society as a result of social forces already at work and increased automation, deliberate planning by governmental and private agencies will be necessary." Striking a quite similar chord Moynihan asserted that : "At the same time there would also seem to be no question that opportunities for a large mass of Negro workers in the lower ranges of training and education have not been improving, that in many ways the circumstances of these workers relative to the white work force have grown worse." This marginalized 
economic status, both scholars suggested, would have ramifying effects, including weakening family structures in ways likely to greatly worsen the challenges faced by

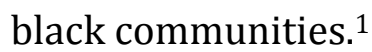

If the backdrop for the scholarly assessments of 1965 was a powerful and transformative mass-based movement for civil rights and an inchoate sense of deep but imminent change, the backdrop for most scholarly assessments today is the election of Barack Obama as President of the United States, the rise of a potent narrative of post-racialism, and a sense of stalemate or stagnation in racial change. There are many meanings or interpretations that might be attached to the term "post-racial." At its simplest and least controversial form the term post-racialism is intended merely to signal a hopeful trajectory for events and social trends more than an accomplished fact of social life. It is something toward which we as a nation still strive and remain guardedly hopeful about fully achieving. There are three other meanings of post-racialism filled with more grounds for dispute and controversy. One meaning of post-racialism attaches to the waning salience of what some have portrayed as a "black victimology" narrative. From this perspective, black complaints and grievances about inequality and discrimination are well-worn tales, at least passé if not now, in fact, pointedly false assessments of the main challenges currently facing blacks in a world largely free of the dismal burdens of overt racial divisions and oppression. ${ }^{2}$

\footnotetext{
${ }^{1}$ St. Clair Drake, "The Social and Economic Status of the Negro in the United States." Daedalus (1965): 3-46; Daniel Patrick Moynihan, "Employment, Income, and the Ordeal of the Negro Family." Daedalus (1965): 134-159.

2 See John McWhorter, Losing the Race; and Charles Johnson, "The End of the Black American Narrative" The American Scholar Summer(2008).
} 
A second and no less controversial view of post-racialism regards the level and pace of change in the demographic make-up and identity choices and politics of Americans as rendering the traditional black-white divide an irrelevance.

Accordingly, Americans increasingly revere mixture and hybridity and are rushing headlong into embracing a decidedly "beige" view of themselves and what is good for the body politic. Old fashioned racial dichotomies pale against the surge toward flexible, de-racialized and mixed ethno-racial identities and outlooks. ${ }^{3}$

A third and perhaps the most controversial view of post-racialism has the most in common with the more well-rehearsed rhetoric of color-blindness. To wit, American society, or at least a large and steadily growing fraction of it, have genuinely moved beyond race. So much so, that we as a nation are now ready to transcend the disabling racial divisions of the past. Nothing symbolizes better this moment of transcendence, from this perspective, than the election of Barack Obama as president of the United States. This transcendence is said to be especially true of a younger generation, what The New Yorker magazine editor David Remnick has referred to as "the Joshua Generation," who more than any others are ready to cross the great river of racial identity, division, and acrimony that has for so long defined American culture and politics.

It is in this context of the first African American president of the United States and the rise to prominence of the narrative of post-racialism that a group of social scientists were asked to examine, from many different disciplinary and

${ }^{3}$ See Hua Hsu, "The End of White America?" Atlantic (January/February 2009); and Saulny, "Black? White? Asian?: More Young Americans Chose All of the Above" New York Times, January 29, 2011. 
intellectual vantage points, changes in the racial divide since the time of the last major Daedalus issue focusing on race in 1965.

The context today, of course, has points of great discontinuity and points of great similarity to that 1965 inflection point. From the vantage point of 1965, the election of Barack Obama as the first African American President of the United States, as well as the expansion and the cultural prominence and success of the black middle class of which Obama is a member, signal the enormous and enduring successes of the civil rights era. Yet also from the vantage point of 1965, the persistence of conditions of deep poverty and joblessness for a large fraction of the black population, slowly changing rates of racial residential segregation by race, continued evidence of anti-black discrimination in many domains of life, and especially historically high rates of black incarceration signal a journey toward racial justice that remains, even by fairly superficial accounting, seriously incomplete.

\section{THE MODERN CONTEXT}

For the purpose of setting a context for the essays contained in this volume I address three key questions in this introduction. The very first concerns racial boundaries themselves. In an era of remarkable widespread talk of having achieved the post-racial society, do we have real evidence that attention to and the meaning of basic race categories are fundamentally breaking down? The second set of questions concerns the extent of economic inequality along the racial divide. Has racial economic inequality narrowed to such an extent that we need no longer think or talk of black disadvantage? Or, have the bases of any race-linked economic 
inequality changed so much that, at the least, the dynamics of discrimination and prejudice no longer need concern us? And the third question is how have racial attitudes changed in the period since the 1965 Daedalus issue?

To foreshadow a bit, I will show that basic racial boundaries are not quickly and inevitably collapsing, though they are changing and under great pressure. Racial economic inequality is a good deal less extreme today, there is a substantial black middle class, and inequality within the black population itself has probably never been greater. Yet, there remain large and durable patterns of blackwhite economic inequality as well, patterns not overcome or eliminated even for the middle class and that still rest to a significant degree upon discriminatory social processes. And, I maintain, we continue to witness the erosion and decline of Jim Crow racist attitudes in the U.S. However, in its place has emerged a new pattern of attitude and belief, variously labeled as symbolic racism, modern racism, color blind racism, or, as I prefer it, laissez faire racism. The latter is a more covert, sophisticated, culture-centered and subtle racist ideology, qualitatively less extreme and more socially permeable form of racism than its predecessor Jim Crow racism with its attendant biological foundations and calls for overt discrimination. But, this new racism is also still a powerful influence in our culture and politics. ${ }^{4}$

\footnotetext{
${ }^{4}$ On Laissez Faire Racism see Lawrence D. Bobo, James R. Kluegel, and Ryan A. SMioth, "Laissez-Faire Racism: The Crystallization of a Kinder, Gentler, Antiblack Ideology." In Racial Attitudes in the 1990s: Continuity and Change, edited by Steven A. Tuch and Jack K. Martin, pp. 15-44 (Greenwood, CT: Praeger, 1997); on modern or symbolic racism see David O. Sears, "Symbolic Racism," in Eliminating Racism: Profiles in Controversy, edited by Phyllis A. Katz and Dalmas A. Taylor, pp. 53-84 (New York: Plenum Press, 1988); and on color-blind racism see Eduardo BonillaSilva, Racism without Racists: Colorblind Racism and Racial Inequality in Contemporary America (Boulder, CO.: Rowman and Littlefield, 2010).
} 
Consider first the matter of group boundaries. The 2000 Census broke new ground by allowing individuals to "mark more than one" box when it came to designating a racial background. Indeed, great political pressure and tumult lead to the Census decision to move in a direction that more formally, institutionally acknowledged the presence of increasing mixture and heterogeneity in the American population with regard to racial background. And nearly 7 million people exercised that option in 2000. The successful rise of Barack Obama to the office of the presidency of the United States, the first African American to do so, as a child of a white American mother and a Black Kenyan father has only accelerated the sense of the new found latitude and recognition granted to those who claim "more than one" racial heritage. ${ }^{5}$

Despite Obama's electoral success and press attention to the phenomenon, it is no doubt surprising to some the degree to which the overwhelming majority of Americans identify with one and only one race. As this first figure shows, less than $2 \%$ of the population marked more than one box in 2000 . Fully $98 \%$ did exactly that and no more. I claim no deep rootedness or profound personal salience for these identities. Rather, the point is that we should be mindful that the level of "discussion" and contention around mixture is somehow far out of proportion to the extent to which most Americans actually appear to designate and see themselves in these terms.

\footnotetext{
${ }^{5}$ See C. Matthew Snipp, "Defining Race and Ethnicity: The Constitution, the Supreme Court, and The Census," in Doing Race: 21 Essays for the $21^{\text {st }}$ Century, edited by Hazel R. Markus and Paula M. L. Moya, pp. 105-122 (New York: Norton, 2010). It is noteworthy that Obama himself checked off only the Black category rather than "marking more than one" on his 2010 Census form.
} 
-- Figure 1 about here --

Moreover, even if we restrict attention just to those who did mark more than one box as Figure 2 shows, two-thirds of these involved two groups other than blacks (that is, namely Hispanic-white, Asian-white, or Hispanic and Asian mixtures). Some degree of mixture with black constituted just under a third of mixed race identifiers in 2000. Given the historic size of the black population and the extended length of contact with white Americans, this is a rather remarkable result and says something powerful, at the least, about the potency and durability of the historic black-white divide.

-- Figure 2 about here --

It is worth recalling, of course, that sexual relations and child-bearing across the racial divide are not recent phenomena. It is easy to forget that the 1890 U.S. Census contained categories not only for "Negro" but also "Mulatto," "Quadroon," and even "Octaroon" designation; clear signs of the extent of "mixing" that had taken place in the U.S. Indeed, well over one million individuals fell into one of the mixed race categories at that time. In order to protect the institution of slavery and to prevent the off-spring of white slave-masters and exploited black slave women from having a claim on freedom as well as on the property of the master, slave status was legally defined as following the mother's status, not the father's. For most of its history the U.S. legally barred or discouraged racial mixing and intermarriage. At 
the time of the Loving v. Virginia case in 1967 there were still 17 states that banned racial intermarriage. ${ }^{6}$

Formal, legal definitions of who was black, and especially the development of rules of "hypo-descent" or the one-drop rule, have a further implication that is often lost in discussions of race: these practices tended to fuse together race and class, in effect, making blackness the very bottom of the class structure. As distinguished historian David Hollinger explained:

"The combination of hypodescent with the denial to blacks residing in many states with large black populations of any opportunity for legal marriage to whites ensured that the color line would long remain to a very large extent a property line. Hence the dynamics of race formation and the dynamics of class formation were, in this most crucial of all American cases, largely the same. This is one of the most important truths about the history of the United States brought into sharper focus when that history is viewed through the lens of the question of ethnoracial mixture."

Still, today we know that the ethno-racial landscape in the U.S. is changing. As of the 2000 Census whites constituted just $69 \%$ of the U.S. population, with Hispanics and Blacks both around $12 \%$ of the total. This distribution represents a substantial decline from the percentage white twenty or even more so, forty years ago.

${ }^{6}$ On the history of "mixing" in the U.S. see Gary B. Nash, "The Hidden History of Mestizo America" Journal of American History 82(1995): 941-964; and Victor Thompson, "The Strange Career of Racial Science: Racial categories and African American Identity," in The Oxford Handbook of African American Citizenship, edited by Henry Louis Gates, Jr. et al., (New York: Oxford University Press, forthcoming). 
With continued immigration, with differential group fertility patterns, and with the continued degree of intermarriage and mixing, these patterns will not remain stable. Figure 3 shows the Census racial distribution projections out to the year 2050. First and most obviously, it continues to show a steady and rapid decline in the relative size of the white population with the forecast that somewhere between 2040 and 2045 whites will cease to a numerical majority of the population (and this change will quite possibly happen much sooner than that). The relative size of the Hispanic population is expected to grow substantially where the Black, Asian, Native Hawaiian and other Pacific Island, as well as American Indian and Alaskan native groups remain relatively constant. This figure makes it clear, at least by strong implication, that pressure to transform our understanding of racial categories will continue.

\section{-- Figure 3 about here --}

Does that pressure for change mean the ultimate undoing of the black-white divide? At least three lines of research raise doubts about such a forecast. First of all, studies of the perceptions of and identities among those of mixed racial backgrounds point to strong evidence of the cultural persistence of the "one-drop rule." Systematic experiments by sociologists and social psychologist are intriguing in this regard. For example, sociologist Melissa Herman's recent research concluded that "others' perceptions shape a person's identity and social understandings of race. My study found that part-black multiracial youth are more likely to be seen as 
black by observers and to define themselves as black when forced to choose one race."7

Studies of patterns of racial intermarriage, secondly, tend to point to a highly durable if somewhat less extreme black-white divide today. A careful assessment of racial intermarriage patterns in 1990 by demographer Vincent Kang Fu found that "one key feature of the data is overwhelming endogamy for blacks and whites. At least 92 percent of white men, white women, black women and black men are married to members of their own group." ${ }^{8}$ Rates of intermarriage rose for blacks and whites over the course of the 1990s. However, subsequent analysts continued to stress the degree to which a fundamental black-white divide persists. As demographers Zhenchao Qian and Daniel Lichter conclude in their analyses of 1990 and 2000 U.S. Census data: "But our results also highlight a singularly persistent substantive lesson: African Americans are least likely of all racial/ethnic minorities to marry whites. And, although the pace of marital assimilation among African Americans proceeded more rapidly over the 1990s than it did in earlier decades, the

\footnotetext{
${ }^{7}$ Melissa R, Herman, "Do You See Who I am?: How Observers' Background affects the perceptions of Multiracial faces." Social Psychology Quarterly 73(2010): 58-78; see also Arnold K Ho, Jim Sidanius, Daniel T. Levin, and Mahzarin R. Banaji, "Evidence for Hypodescent and Racial Hierarchy in the Categorization and Perception of Biracial Individuals" Journal of Personality and Social Psychology 94(2010): 1-15.

8 Vincent Kang Fu, "How Many Melting Pots?: Intermarriage, Pan ethnicity, and the Black/Non-black Divide in the United States" Journal of Comparative Family Studies 38 (2007): 215-237. See on the point of a racial preference hierarchy Vincent Kang $\mathrm{Fu}$, “Racial Intermarriage Pairings" Demography 38(2001): 147-159.
} 
social boundaries between African American and whites remain highly rigid and resilient to change. The 'one-drop' rule apparently persists for African Americans". ${ }^{9}$

Thirdly, some key synthetic works argue for an evolving racial scheme in the U.S., but a scheme that nonetheless preserves a heavily stigmatized black category. A decade ago sociologist Herbert Gans offered the provocative but well-grounded speculation that we would witness a transition in the U.S. from a society defined by a great White-nonWhite divide, to one increasingly defined by a Black-Non-black fissure, with an in-between or residual category for those granted provisional or Honorary White States. As Gans explained: “If current trends persist, today's multiracial hierarchy could be replaced by what I think of as a dual or bimodal one consisting of 'nonblack' and 'black' population categories, with a third 'residual' category for the groups that do not, or do not yet, fit into the basic dualism." Most troubling, this new dualism would, in Gans expectations, continue to bring a profound sense of undeservingness and stigma for those assigned it's bottom rung. ${ }^{10}$

Gans's remarks have recently received substantial support from demography Frank Bean and his colleagues. Based on their extensive analyses of population

\footnotetext{
${ }^{9}$ Zenchao Qian and Daniel T. Lichter, "Social Boundaries and Marital Assimilation: Interpreting Trends in Racial and Ethnic Intermarriage" American Sociological Review 72 (2007), pp. 68-94. See also Zenchao Qian, "Breaking the Last Taboo: Interracial Marriage in America" Contexts 4(2005): 33-37.

${ }^{10}$ Herbert J. Gans. "The Possibility of a New Racial Hierarchy in the Twenty-First Century United States" in The Cultural Territories of Race, edited by Michele Lamont, pp. 371-390 (New York: Russell Sage Foundation, 1999); and Frank D. Bean, et al., "The New U.S. Immigrants: How do they Affect Our Understanding of the African American Experience?" Annals of the American Academy of Political and Social Science 621(2009): 202-220. For closely related discussions see Mary C. Waters, Black Identities: West Indian Immigrant Dreams and American Realities (Cambridge: Harvard University Press, 1999); and Milton Vickerman, "Recent Immigration and Race: Continuity and Change," Du Bois Review 4(2007): 141-165.
} 
trends across a variety of indicators Bean and colleagues write: "A black-nonblack divide appears to be taking shape in the United States, in which Asians and Latinos are closer to whites. Hence, America's color lines are moving toward a new demarcation that places many blacks in a position of disadvantage similar to that resulting from the traditional black-white divide."

If basic racial categories and identities are not about to dissolve, then let me now shift gears explicitly to that second set of questions about the degree of racial economic inequality. The first thing to note is that there has been considerable expansion in the size, security, and arguably salience and influence of the black middle class. ${ }^{11}$

When we turn to the question of income something of a similar trend is evident. Figure 4 reports on the distribution of the population by race since 1968 across several ways of slicing the family income distribution. At the very bottom are those who the Census would designate as "the very poor," who have a family income that is $50 \%$ or less of the poverty level. At the very top are those in the "comfortable" category who have family incomes that are 5 times or more the poverty level. The proportion of whites in this upper category exceeded $10 \%$ in 1960 and rose to nearly $30 \%$ by 2008 . For blacks, that number was less than $5 \%$ in 1968 but it rose to about $12 \%$ in 2008 . Likewise, the fraction middle class grows for both groups (those with family incomes more than twice the poverty level). But,

${ }^{11}$ See Bart Landry, The New Black Middle Class (Berkeley, CA.: University of California Press, 1987); Karyn Lacy, Blue Chip Black: Race, Class and Status in the New Black Middle Class (Berkeley, CA.: University of California Press, 2007); and Mary Pattillo, Black on the Block: The Politics of Race and Class in the City (Chicago: University of Chicago Press, 2007). 
crucially, the proportion of blacks in the poor (at the poverty line) or very poor, remains large, at a combined figure of nearly $40 \%$ in 2008 . This contrasts to a comparable figure of around $20 \%$ for whites. ${ }^{12}$

-- Figure 4 about here --

The official black poverty rate has fluctuated between to 2 to 3 times the poverty rate for white. Recent trend analyses suggest that this disparity declined during the economic boom years of the 1990s but remained substantial. As public policy analyst Michael Stoll explains: "Among all black families, the poverty rate declined from a 20 year high of about 40 percent in 1982 and 1993 to 25 percent in 200. During this period, the poverty rate for white families remained fairly constant, at about 10 percent." That figure of $25 \%$ remains true through more recent estimates. In addition, the Great Recession has taken a particularly heavy toll on minority communities, African Americans perhaps most of all. As the Center for American Progress declared in a recent report: "Economic security and losses during the recession and recovery exacerbated the already weak situation for African Americans. They experienced declining employment rates, rising poverty rates, falling homeownership rates, decreasing health insurance and retirement

${ }^{12}$ See Michael A. Stoll, "African Americans and the Color Line" in The American People: Census 2000, edited by Reynolds Farley and J. Haaga, pp. 380-414, especially p. 395; and Lawrence D. Bobo, "An American Conundrum: Race, Sociology, and the African American Road to Citizenship" in The Oxford Handbook of African American Citizenship, edited by Henry Louis Gates Jr., et al (New York: Oxford University Press, forthcoming). 
coverage during the last business cycle from 2001 to 2007. The recession that followed made a bad situation much worse".$^{13}$

Overall trends in poverty, however, do not fully capture the cumulative, and multidimensional nature of black economic disadvantage. Distinguished sociologist William Julius Wilson stresses how circumstances of persistently weak employment prospects and joblessness, particularly for low skilled black men, weaken the formation of stable two-parent households and undermine other community structures. Persistent economic hardship and weakened social institutions then create circumstances that led to rising rates of single parent households, out-ofwedlock child-bearing, welfare dependency, and greater risk of juvenile delinquency and involvement in crime. Harvard sociologist Robert Sampson points to an extraordinary circumstance of exposure to living in deeply disadvantaged communities for large segments of the African American population. This deep disadvantage involves living in conditions that expose one to high surrounding rates of unemployment, family break-up, individuals and families reliant on welfare, poor performing schools, juvenile delinquency, and crime. As Sampson explained: "although we knew that the average national rate of family disruption and poverty among blacks was two to four times higher than among whites, the number of distinct ecological contexts in which black achieve equality to whites is striking. In not one city or 100,000 or more in the United States do blacks live in ecological equality with whites when it comes to these basic features of economic and family

${ }^{13}$ Christian E. Weller, Jaryn Fields, and Folayemi Agbede, "The State of Communities of Color in the U.S. Economy," Center for American Progress, Http://www.americanprogress.org/issues/2011/01/coc_snapshot.html/print.html accessed 1/23/11 2:50 pm. 
organization. Accordingly, racial differences in poverty and family disruption are so strong that the 'worst' urban contexts in which whites reside are considerably better than the average context of black communities". ${ }^{14}$

Recent work published by sociologist Patrick Sharkey assesses race differences in the chances of mobility out of poverty neighborhoods. The result is a very depressing one. He finds evidence of little upward social mobility for disadvantaged blacks and a fragile capacity to maintain advantaged status among even the most well-off African Americans. He writes: “...more than 70\% of black children who are raised in the poorest quarter of American neighborhoods will continue to live in the poorest quarter of neighborhoods as adults. Since the 1970s, more than half of black families have lived in the poorest quarter of neighborhoods in consecutive generations, compared to just $7 \%$ of white families." At the upper end he writes, "Among the small number of black families who live in the top quartile, only $35 \%$ remain there in the second generation. By themselves, these figures reveal the striking persistence of neighborhood disadvantage among black families". This figure of $35 \%$ remaining in the top quartile across generations for blacks contrasts to $63 \%$ among whites. To wit "White families exhibit a high rate of

\footnotetext{
${ }^{14}$ William Julius Wilson, The Truly Disadvantaged: The Inner City, the Underclass, and Public Policy. (Chicago: University of Chicago Press, 1987); William Julius Wilson, When Work Disappears: The World of the New Urban Poor. (New York: Knopf, 1996); and Robert J. Sampson, "Urban Black Violence: The Effect of Male Joblessness and family Disruption" American Journal of Sociology 93(1987): 348382.
} 
mobility out of the poorest neighborhoods and a low rate of mobility out of the most affluent neighborhoods, and the opposite is true among black families." ${ }^{15}$

The general labor market prospects of African Americans have undergone key changes in the last several decades. Three patterns loom large. There is far more internal differentiation and inequality within the black population than was true at the close of World War II, or even taking our baseline of the mid-1960s. The fortunes of men and women have recently diverged within the black community. Black women have considerably narrowed the gap between themselves and white women in terms of educational attainment, major occupational categories, and even earnings. Black men have faced a growing problem of economic marginalization. But, this is importantly contingent on levels of education. Education has become a far sharper dividing line shaping life chances than ever before in the black community. ${ }^{16}$

Several other dimensions of socio-economic status are worthy of mention. It remains the case that even by conservative estimates, blacks have twice the level of high school drop-out as whites, $20 \%$ versus $11 \%$. Blacks also have much lower college completion rates, $17 \%$ versus $30 \%$, and lower advanced degree completion rates, $6 \%$ for blacks versus $11 \%$ for whites. These differences are enormously consequential. As the essays by Nobel-laureate James Heckman and distinguished

15 Patrick Sharkey, "The Intergenerational Transmission of Context" American Journal of Sociology, 113(4): 931-969. See also Tom Hertz "Rags, riches, and race: The Intergenerational Economic Mobility of Black and White Families in the United States," in Unequal Chances: Family Background and Economic Success, edited by Samuel Bowles, Herbert Gintis, and Melissa Osborne Groves, pp. 165-191 (Princeton, NJ.: Princeton University Press, 2005).

${ }^{16}$ See Michael B. Katz, Mark J. Stern, and Jamie J. Fader, "The New African American Inequality" Journal of American History (2005): 75-108. 
social psychologist Richard Nisbett emphasize, education attainment and achievement increasingly define access to the good life, broadly defined. Moreover, some scholars make a strong that important inequalities in resources still plague the educational experiences of many black school children, involving such factors as fewer well-trained teachers, less access to AP courses and other curriculum enriching materials and experiences. ${ }^{17}$

One of the major social trends affecting African Americans over the past several decades has been the sharply punitive and incarceration focused turn in the American criminal justice system. Between 1980 and 2000 the rate of black incarceration nearly tripled. The black-to-white incarceration ratio increased to above 8-to-1 during this time period. Actuarial forecasts or life-time estimates of the risks of incarceration for black male born in the 1990s approach 1 in 3, where the rates is below 1 in 10 for nonhispanic white males. A recent major study by the Pew Foundation reported that as of 20071 in 15 black males 18 and above was in jail or prison and 1 in 9 black males between the ages of 20 and 34 were in jail or prison. Blacks constitute a hugely disproportionate share of those incarcerated relative to their numbers in the general population. ${ }^{18}$

\footnotetext{
${ }^{17}$ Linda Darling Hammond, "The Color Line in American Education: Race, Resources, and Student Achievement" Du Bois Review 1(2004): 213-246; and Linda Darling Hammond, "Structured for Failure: Race, Resources, and Student Achievement" in Doing Race: 21 Essays for the $21^{\text {st }}$ Century, edited by Hazel R. Markus and Paula M. L. Moya, pp. 295-321 (New York: Norton, 2010).

${ }^{18}$ Alfred Blumstein, "Race and Criminal Justice" in America Becoming: Racial Trends and Their Consequences, vol 2, edited by Neil J. Smelser, William Julius Wilson, and Faith Mitchell, pp. 21-31 (Washington, DC: National Academy Press, 2001); and Pew Center on the States, “One in 100: Behind Bars in America 2008." Washington, DC: Pew Charitable Trusts.
} 
The reach of mass incarceration has risen to such levels that some analysts view it as altering normative life course experiences for blacks in low income neighborhoods. Indeed, the fabric of social life changes in heavily policed, lowincome urban communities. The degree of incarceration has prompted scholars to describe the change as ushering a new $4^{\text {th }}$ stage of racial oppression labeled the carceral state; to constitute the emergence or "the new Jim Crow," or more narrowly to amount to racialized mass incarceration. Whichever label one employs there is no denying that exposure to the criminal justice system touches the lives of a large fraction of the African American population, especially young men of low education and skill levels. These low levels of education and greater exposure poverty, along with what many regard as the racially biased conduct of the "War on Drugs" play a huge role in black overrepresentation of those in jail or federal and state prisons. ${ }^{19}$

Processes of racial residential segregation are a key factor in contemporary racial inequality. Despite important declines in overall rates of segregation over the past three decades and the increasing suburbanization of blacks, blacks remain highly segregated from whites. Some have suggested that active self-segregation on

${ }^{19}$ Generally see Bruce Western, Punishment and Inequality in America (New York: Russell Sage Foundation, 2006). On changes in the normative life trajectories see Becky Pettit and Bruce Western, "Mass Imprisonment and the Life-Course; Race and Class Inequality in U. S. Incarceration" American Sociological Review 69(2004): 151169. On the social costs of heavy police scrutiny of poor neighborhoods see Loic Wacquant, "Deadly Symbosis: When Ghetto and Prison Meet and Mesh" Punishment and Society 3(2001): 95-135; and Alice Goffman, "On the Run: Wanted Men in a Philadelphia Ghetto." American Sociological Review 74(2009): 339-357. One the broad character of rising incarceration rates for blacks see Lawrence D. Bobo and Victor Thompson, "Racialized Mass Incarceration: Poverty, Prejudice, and Punitiveness" in Doing Race: 21 Essays for the $21^{\text {st }}$ Century, edited by Hazel R. Markus and Paula M. L. Moya, pp. 322-355 (New York: Norton 2010); andMichele Alexander, The New Jim Crow: Mass Incarceration in the Age of Colorblindness (New York: The New Press, 2010). 
the part of blacks is now a major factor sustaining residential segregation. A number of careful investigations of preferences for neighborhood characteristics and make-up, the housing search process, and the like strongly challenge such claims. Instead, there is substantial evidence that, particularly among white Americans, neighborhoods and social spaces are strongly racially coded, with negative racial stereotypes playing a powerful role in shaping the degree of willingness to enter (or remain) in racially integrated living spaces. And, moreover, careful auditing studies continue show lower but still significant rates of anti-black discrimination on the part of real estate agents, home-owners, and apartment renters. ${ }^{20}$

Lastly, I want to stress that wealth inequality between black-white remains enormous. Recent scholarship has convincingly argued that wealth, or accumulated assets, are a crucial determinant of ultimate quality of life. Blacks at all levels of the class hierarchy typically possess far less wealth than otherwise comparable whites. Moreover, the composition of black wealth is more heavily based in homes and automobiles as compared to white wealth which includes a more even spread across savings, stocks and bonds, business ownership, and other more readily liquidated

${ }^{20}$ Generally see Douglas S. Massey and Nancy A. Denton, American Apartheid: Segregation and the Making of the Underclass (Cambridge: Harvard University Press, 1993); Camille Z. Charles, Won't You be My Neighbor?: Race, Class, and Residence in Los Angeles (New York: Russell Sage Foundation, 2006); Robert J. Sampson, "Seeing Disorder: Neighborhood Stigma and the Social Construction of 'Broken Windows'” Social Psychology Quarterly 67(2004): 319-342; Maria Krysan, Mick Couper, Reynolds Farley, and Tyrone A. Forman, "Does Race Matter in Neighborhood Preferences?: Results from a Video Experiment" American Journal of Sociology (2009): 527-559; and Devah Pager and Hana Sheperd, "The Sociology of Discrimination: Racial Discrimination in Employment, Housing, Credit, and Consumer Markets" Annual Review of Sociology 34(2008): 181-209.a 
assets. Whereas approximately $75 \%$ of white own their own homes only $47 \%$ of blacks do. Looking beyond home ownership to the full range of financial assets, analyses from Melvin Oliver and Tom Shapiro but the black-to-white wealth gap ratio in the 10 or 11-to- 1 ratio range. Other estimates, like those shown here based on Panel Study of Income Dynamics data, are lower but still represent gaping disparities. $^{21}$

In order to provide a more concrete picture of the current state of the wealth gap figure 5 reproduces results from a recent Brandeis University study. It shows that over the past 23 years the black-white gap in median wealth rose dramatically, moving $\$ 20,000$ in 1984 to nearly $\$ 100,000$ by 2007 . The study also revealed that for much of this time period even middle income white families had more wealth than even the highest income segment of African American families, with that gap rising to $\$ 56,000$ by 2007 . Moreover, all earners, but especially African Americans, have fallen far behind the high income white families in median wealth holdings. To the extent that wealth bears on the capacity to survive a spate of unemployment, to finance college for one's children, or to endure a costly illness or other unexpected large expense, these figures point to an enormous and growing disparity in the life chances of blacks and whites in the U.S. ${ }^{22}$

\footnotetext{
${ }^{21}$ Melvin L. Oliver and Thomas M. Shapiro, Black Wealth/White Wealth: A New Perspective on Racial Inequality (New York: Routledge, 1995); Dalton Conley, Being Black, Living in the Red: Race, Wealth, and Social Policy in America (Berkeley, CA.: University of California Press, 1999); and Thomas M. Shapiro, The Hidden Cost of Being African American: How Wealth Perpetuates Inequality (New York: Oxford University Press, 2004).

${ }^{22}$ Thomas M. Shapiro, Tatjana Meschede, and Laura Sullivan. "The Racial Wealth Gap Increases Fourfold" Research and Policy Brief, Institute on Assets and Social Policy, Brandeis University, May 2010.
} 
-- Figure 5 about here --

In many respects, these sizeable gaps in wealth associated with race are one of the principal ways in which the cumulative and "sedimentary" impact of a long history of racial oppression is manifest. Research has shown that black and white families do not differ substantial in the extent to which they try to save income. Much wealth is inherited, not the product of strictly individual merit or achievement. Furthermore, social policy in many ways played a direct role in facilitating the accumulation of wealth for many generations of white Americans while systematically constraining or undermining such opportunities for African Americans. For example, sociologists Oliver and Shapiro and political scientist Ira Katznelson both point to federal home mortgage lending guidelines and practices, which were once openly discriminatory, as playing a crucial role in this process. ${ }^{23}$

What do we know about changes in racial attitudes in the U.S.? The first and most consistent finding of the major national studies of racial attitudes in the U.S. has been a steady repudiation of the outlooks that supported the Jim Crow social order. Jim Crow racism once reigned in American society, particularly in the south. Accordingly, blacks were the inherently intellectually and temperamentally lesser than whites. As a result, society was to be expressly ordered in terms of white privilege with blacks relegated to secondary status in education, access to jobs, and in civic status such as the right to vote. And, above all else, racial mixture was to be avoided hence we should be segregated society. The best survey data on American

\footnotetext{
${ }^{23}$ See Ira Katznelson, When Affirmative Action Was White: An Untold Story of Racial Inequality in Twentieth Century America (New York: Norton, 2005).
} 
public opinion suggests that this set of ideas has been in steady retreat since the $1940 s^{24}$

One telling illustration of this trend is contained in Figure 6 which shows the percentage of white Americans in national surveys saying that they would NOT be willing for a vote for a qualified black candidate for president if nominated by their own party. When first asked in 1958 nearly 2 out of 3 white American endorsed such an openly discriminatory posture. That trend undergoes unabated decline to the point where only roughly 1 in 5 white Americans expressed this view by the time the Reverend Jesse Jackson launched his first bid for the democratic presidential nomination in 1984 . It declined to fewer than 1 in 10 by the time of Obama's campaign in 2008.

-- Figure 6 about here --

In broad sweep and trend, though not necessarily in exact levels, the trend seen in Figure 6 is true of most questions on racial attitudes from national surveys that deal with broad principles of whether American society should be integrated or segregated, discriminatory or non-discriminatory on the basis of race. Whether the specific domain involved school integration, residential integration, or even racial intermarriage, the level of endorsement of the discriminatory, segregationist

24 This dicussion of racial attitudes owes much in general to Howard Schuman, Charlotte Steeh, Lawrence D. Bobo and Maria Krysan, Racial Attitudes in America: Trends and Interpretations (Cambridge: Harvard University Press, 1997). See also Lawrence D. Bobo, "Racial Attitudes and Relations at the Close of the Twentieth Century," in America Becoming: Racial Trends and Their Consequences, Vol. 1, edited by Neil J. Smelser, William Julius Wilson, and Faith Mitchell, pp. 264-301 (Washington, DC: National Academy Press, 2001); and Maria Krysan, "From Color Caste to Color Blind?: Racial Attitudes Since WWII," in The Oxford Handbook of African American Citizenship, edited by Henry Louis Gates Jr., et al. (New York: Oxford University Press, forthcoming). 
responses has continued to decline. These changes have been lead to an important degree by the highly educated whites and those outside the south. African Americans have never endorsed elements of the Jim Crow outlook to any substantial degree, thought many of these questions were not initially asked of black respondents out of fear that the questions would be regarded as insulting on the assumptions that their responses were predictable.

This picture of the repudiation of Jim Crow is complicated somewhat by evidence of significant social distance preferences. To be sure, low and typically declining percentages of whites objected when asked about entering into integrated social settings-neighborhoods or schools—where one or just a small number of blacks might be present. But as the number of blacks involved increased and as one shifts from more impersonal and public domains of life (i.e., work places, schools, neighborhoods) to more intimate and personal domains (i.e., intermarriage) expressed levels of white resistance rise and the degree of positive change is not as great.

The notion of the 1960s as an inflection point in the struggle for racial change is reinforced by the growing pre-occupation of studies of race attitudes in the post 1960 period on levels of support or opposition to public policies designed to bring about greater racial equality (anti-discrimination laws and various forms of affirmative action) and actual integration (open housing laws and methods of school desegregation such as school busing). The picture that results is complex but has several recurrent features. Blacks are typically far more supportive of social policy intervention on matters of race than are whites. In general, support for policy or 
governmental intervention to bring about greater integration or to reduce racial inequality lags well behind endorsement of similar broad principles or ideals. This has led many scholars to note a "principle-implementation gap." Some policies, however, have wider appeal than others. Efforts to enhance or improve the human capital attributes of blacks and other minority group members are more popular than policies that call for group preferences. Forms of affirmative action that imply quotas or otherwise disregard meritocratic criteria of reward are deeply unpopular.

One important line of investigation seeking to unpack the "principleimplementation gap" involved assessments of perceptions and causal attributions for racial inequality. To the extent many individuals do not perceive much racial inequality, or explain it in terms of individual dispositions and choices (as opposed to structural constraints and conditions such as discrimination), then there is little need seen for a government obligation to take action. Table 1 shows responses to a series of questions on possible causes of black-white economic inequality ranging from "less in-born ability," "lack of motivation and will power," "no "chance for an education," and "mainly due to discrimination." The questions thus range from biologically based (ability), to cultural (motivation), to a weak form of structural constraints (education), to finally a strong structural constraint (discrimination). ${ }^{25}$

\footnotetext{
${ }^{25}$ Important early work on attributions for racial inequality appears in Howard Schuman, "Sociological Racism," Society 7(1969): 44-48; Richard Apostle et al., The Anatomy of Racial Attitudes (Berkeley, CA.: University of California Press, 1983); James R. Kluegel and Eliot R. Smith, Beliefs About Inequality: Americans' Vies of What is and What Ought to Be. (New York: Aldine de Gruyter, 1986); Paul M. Sniderman and Michael G. Hagen, Race and Inequality: A Study in American Values (Chatham, NJ.: Chatham House, 1985); and James R. Kluegel "Trends in Whites' Explanations of the Black-White Gap in Socioeconomic Status, 1977-89" American Sociological Review 55(1990): 512-525.
} 
-- Table 1 about here --

There is low and decreasing support among whites for the overtly racist belief that blacks have less in-born ability. The most widely endorse account among whites points to a lack of motivation or will power on the part of blacks as a key factor in racial inequality, though this attribution declines over time. Attributions to discrimination as well as to the weaker structural account of lack of a chance for education also decline among whites. Blacks are generally far more likely than whites to endorse structural accounts of racial inequality, particularly the strongest attribution of discrimination. However, like their white counterparts, a decline number of blacks point to discrimination as the key factor and there is actually a rise in the percentage of African Americans attributing racial inequality to a lack of motivation or will power on the part of blacks themselves. More detailed multivariate analyses suggest that there has been growth in cultural attributions for racial inequality. Among African Americans this seems most prominent among somewhat younger, ideologically conservative, and less well-educated individuals. ${ }^{26}$ Another line of analysis of racial attitudes sparked in part by the "principleimplementation gap" involved renewed interest in the extent of negative racial stereotyping. Figure 7 shows trends in whites stereotype trait ratings of whites as compared to blacks on the dimensions of being hard working or lazy and intelligent or unintelligent. When these trait rating stereotype questions were first posed in

\footnotetext{
${ }^{26}$ Matthew O. Hunt. "African-American, Hispanic, and White Beliefs about Black/White Inequality, 1977-2004" American Sociological Review 72 (2007) 390415; Lawrence D. Bobo et al., "The Real Record on Racial Attitudes" in Social Trends in the United States 1972-2008: Evidence from the General Social Survey, edited by Peter V. Marsden (Princeton, NJ.: Princeton University Press, forthcoming).
} 
national surveys in 1990, more than 60 percent of whites rated whites as more likely to be hard working than blacks and just under 60 percent rated blacks as less intelligent. A variety of other trait dimensions were included in this early assessment, such as welfare dependency, involvement in drugs and gangs, and levels of patriotism. Whites usually expressed substantially negative image of blacks relative to how they rated whites across this array of traits. The trends suggest some slight reduction in negative stereotyping over the past two decades, but such negative images of blacks still remain quite common place. To the extent that unfavorable beliefs about the behavioral characteristics of blacks have a bearing on levels of support for policies designed to benefit blacks, these data imply, and much evidence confirms, that negative beliefs about blacks' abilities and behavioral choices contribute to the low levels of white support for significant social policy interventions to ameliorate racial inequality. ${ }^{27}$

-- Figure 7 about here --

A third and perhaps most vigorously considered resolution of the principleimplementation gap involves the hypothesis that a new form of antiblack racism is at the root of much white opposition to policies aimed at reducing racial inequality.

27 On the stereotype measures see Tom W. Smith, "Ethnic Images" GSS Technical Report No. 19, Chicago, IL.: National Opinion Research Center; and Lawrence D. Bobo and James R. Kluegel. "Status, Ideology, and Dimensions of Whites' Racial Beliefs and Attitudes: Progress and Stagnation" In Racial Attitudes in the 1990s: Continuity and Change, edited by Steven A. Tuch and Jack K. Martin, pp. 93-120 (Greenwood, CT.: Praeger, 1997). On the stereotype connection to public policy views see Martin I. Gilens, Why Americans Hate Welfare: Race, Media, and the Politics of Antipoverty Policy (Chicago: University of Chicago Press, 1999); Bobo, Lawrence D. Bobo and James R. Kluegel, "Opposition to Race-targeting: Self-Interest, Stratification Ideology, or Racial Attitudes?" American Sociological Review 58(1993): 443-464; and Steven A. Tuch and Michael Hughes, "Whites' Racial Policy Attitudes." Social Science Quarterly 77(1996): 7223-745. 
Much of this scholarship has focused on the emergence of attitudes of resentment toward the demands or grievances voiced by African Americans and the expectation of governmental redress for those demands and grievances. Figure 8 shows trends for one question frequently used to tap such sentiments which asks respondents to agree or disagree with the statement that "Irish, Italian, Jewish and many other minorities overcame prejudice and worked their way up. Blacks should do the same without special favors." Throughout the 1994 to 2008 time span, roughly threefourths of white American agreed with this assertion. The item shows no meaningful trend, despite a slight dip in 2004: the lopsided view among whites is that blacks need to make it all on their own. ${ }^{28}$

-- Figure 8 about here --

Throughout the 14 year time span, whites are always substantially more likely to endorse this viewpoint than blacks, but not only do a non-trivial number of blacks agree with it (about 50\%): the black-white gap actually narrows slightly over time. But the meaning and effects of this type of outlook vary in important ways depending on race, usually carrying less potent implications for policy views among blacks than it does among whites. Indeed, one reason for focusing on this type of attitude is that it and similar items are found to correlate no only with a wide range

\footnotetext{
${ }^{28}$ For one excellent empirical report see David O. Sears, Collette van Larr, Mary Carillo, and Rick Kosterman, "Is it really Racism?: The origins of White American Opposition to Race-Targeted Policies" Public Opinion Quarterly 61(1997): 16-53. For a careful review and assessment of debates regarding the new racism hypothesis see Maria Krysan, "Prejudice, Politics, and Public Opinion: Understanding the Sources of Racial Policy Attitudes" Annual Review of Sociology 26(2000): 135-168.
} 
of social policy outlooks, there is some evidence that strength of that connection to partianship and voting behavior may be growing. ${ }^{29}$

\section{CONCLUSION}

Judged by the trends considered here and in the essays in this volume, declarations of the having arrived at the post-racial moment are premature. Much has changed and unequivocally changed for the better judged against the benchmark of where the U.S. stood in 1965. Indeed, changes I will speculate that none of the contributors to the 1965 volumes would have considered likely a mere four or so decades later, such as the election of an African American president of the United States (or, for that matter, the appointments of the first black chair of the Joint Chiefs of Staff and two different African American Secretaries of State), have in fact been realized. Similarly, the size and reach of today's black middle class was not easy to forecast from the scholarly perch of 1965 data and understandings. At the same time, troublingly entrenched patterns of poverty, segregation, gaps in educational attainment and achievement, racial identity formation, and disparaging racial stereotypes all endure into the present, even if in somewhat less extreme form. And the scandalous rise in what is now termed racialized mass incarceration had not been foreseen and adds a new measure of urgency to these concerns.

\footnotetext{
${ }^{29}$ For the growing role of such resentments in partisan outlooks and political behavior see Nicholas A. Valentino and David O. Sears, "Old Times There Are Not Forgotten: Race and Partisan Realignment in the Contemporary South" American Journal of Political Science 49(2005): 672-688. For differential effects by race see Lawrence D. Bobo and Devon Johnson, "A Taste for Punishment: Black and White Americans' Views on the Death Penalty and the War on Drugs" Du Bois Review 1(2004): 151-180.
} 
The very complex and contradictory nature of these changes caution against the urge to make sweeping and simple declarations about where we now stand. But, this "mixed" or ambiguous circumstance wherein we as a nation stand uncomfortably suspended somewhere between the collapse of the Jim Crow social order and the as yet unattained truly post-racial social order, naturally gives rise to many intense exchanges over whether or how much "race matters." This is true of scholarly discourse where many see racial division as a deeply entrenched and tragic American flaw and many others see racial division as a waning exception to the coming triumph of American liberalism. ${ }^{30}$

Average black and white Americans face and wage much the same debate in their day-to-day lives. One way of capturing this dynamic is illustrated in Figure 9 which shows the percentage of white and black respondents from a 2009 national

30 Those representative of the deeply rooted racial flaw camp would include Derrick Bell, Faces at the Bottom of the Well: The Permanence of Racism (New York: Basic Books, 1992); Andrew Hacker, Two Nations: Black and White: Separate, Hostile, Unequal (New York: Scribner, 1992); Donald R. Kinder and Lynn M. Sanders, Divided by Color: Racial Politics and Democratic Ideals (Chicago: University of Chicago Press, 1996); Charles W. Mills, The Racial Contract (New York, Ithaca: Cornell University Press, 1997); Joe R. Feagin, Racist America: Roots, Current Realities, and Future Reparations (New York: Routledge, 2000); Michael K. Brown et al., White-Washing Race: The Myth of a Color-Blind Society (Berkeley, CA.: University of California Press, 2003); and Douglas S. Massey, Categorically Unequal: The American Stratification System (New York: Russell Sage Foundation, 2006). Those representative of the triumph of American liberalism would include Nathan Glazer, "The Emergence of an American Ethnic Pattern," in From Different Shores: perspectives on Race and Ethnicity in America, edited by Ronald Takaki, pp. 11-23 (New York: Oxford University Press, 1987); Orlando Patterson, The Ordeal of Integration: Progress and Resentment in America's 'Racial' Crisis (Washington, DC: Basic Civitas, 1997; Paul M. Sniderman and Edward G. Carmines. 1997. Reaching Beyond Race (Cambridge: Harvard University Press, 1997); and Abigail Thernstrom and Stephan Thernstrom, America in Black and White: One Nation, Indivisible (New York: Simon \& Schuster, 1997); and Richard D. Alba, Blurring the Color Line: The New Chance for a More Integrated America (Cambridge: Harvard University Press, 2009). 
survey who were asked: “ Do you think blacks have achieved racial equality, will soon achieve racial equality, will not achieve racial equality in your lifetime, or will never achieve racial equality?" Fielded after the 2008 election and the inauguration of Obama in early 2009, these results are instructive. Almost 2 out of 3 white Americans (61.3 percent) said that we have achieved racial equality. Another 21.5 percent of whites endorse the view that we will soon achieve racial equality. Thus, the overwhelming fraction of white Americans see the post-racial moment as effectively here (83.8 percent). Fewer than 1 in 5 blacks endorsed the idea that we have already achieved racial equality. A more substantial fraction, 36.2 percent believe that we will soon achieve racial equality. African Americans are divided almost evenly then between those doubtful that racial equality will soon be achieved (with more than 1 in 10 saying it will never be achieved) and those who see equality as within reach, 46.6 versus 53.6 percent. $^{31}$

-- Figure 9 about here --

These results certainly underscore why discussions of race so easily and quickly become polarized and fractious along racial lines. The central tendencies of public opinion on these issues, despite real increasing overlap, remain enormously far apart between black and white Americans. When such differences in perception

31 These numbers point to a sharp rise in the percentage of white Americans endorsing the view that we have or will soon achieve racial equality, up from about 66 percent in 2000 to over 80 percent in 2009. The similar figures for blacks are $27 \%$ in 2000 rising to $53.4 \%$ in 2009 , or nearly double. The 2000 survey allowed response of "Don't Know" whereas the 2009 survey did not. These comparisons are percentaged without the don't know responses. The 2000 results are reported in Lawrence D. Bobo, "Inequalities that Endure?: Racial Ideology, American Politics, and the Peculiar Role of the Social Sciences" in The Changing Terrain of Race and Ethnicity, edited by Maria Krysan and Amanda E. Lewis, pp. 13-42 (New York: Russell Sage Foundation, 2004). 
and belief are grounded in, or at least reinforced by, wide economic inequality, persistent residential segregation, still largely racially homogeneous family units and close friendship networks, and a popular culture still suffused with negative ideas and images about African Americans, then there should be little surprise that we still find it enormously difficult to have sustained civil discussions about race and racial matters. Despite growing much closer together in recent decades, the gaps in perspective between blacks and whites are still sizeable.

The ideas and evidence marshaled in this Daedalus issue should help to sharpen our focus and to open up productive new lines of discourse and inquiry. Four of the essays directly engage central but changing features of racial stratification in the U.S. Douglas Massey provides a trenchant, broad gauge mapping of change in the status of African Americans. William Julius Wilson reviews and assesses his field-defining argument about the "declining significance of race." The core framework is sustained, he maintains, by much subsequent careful research but Wilson stresses now the special importance of employment in the government sector to the economic well-being of many African Americans. James Heckman takes a special focus on education, building the case for enhancing the capacities of families and communities to prepare children to get the most of out schooling. Richard Nisbett, similarly, focuses on the types of early intervention strategies that evidence suggests are most likely to improve ultimate educational attainment and achievement.

Three of the essays put the changing status of African Americans in more explicit political, policy related, and legal perspective. Political scientist Rogers 
Smith and colleagues identify the pivotal role played by agents of competing racial policy coalitions, pointing to the differing agendas and degrees of political success and influence of those pursing a colorblind strategy and those pursuing a color conscious strategy. Legal scholar Richard Klarman challenges the presumption that the U.S. Supreme Court has been a special ally or supporter of African American interests and claims. He suggests that the court has often, particularly in a string of recent rulings, tilted heavily in the direction of a colorblind set of principles that do little to advance the interests of black communities. Daniel Sabbagh traces the impetus for affirmative action and its evolution in the U.S. and compares that to how affirmative action is now pursued in a number of other countries.

Several of the essays examine the cultural dynamics of race and racial identities. Anthropologists Marcyliena Morgan and Dionne Bennett examine the remarkable dynamism, world-wide spread and influence of Hiphop music. Social psychologists Jennifer Richeson and Maureen Craig examine the psychological dynamics of identity choices facing minority communities and individuals in this era of rapid population change. Political scientist Jennifer Hochschild and her colleagues assess how younger cohorts of Americans are bringing different views of race and its importance to politics and social life.

Several of the essays pivot centrally off of the 2008 presidential elections. Political scientist Taeku Lee examines the complex role of race, group identity, and immigrant status in forging new political identities, coalitions and voting behavior. Cathy Cohen shows the continuing racial consciousness and orientations of black 
youth. Sociologist Alford Young examines the special meaning of the Obama candidacy and his success for young black men.

Two final essays push in quite different directions. Sociologist Roger Waldinger argues that even as the black-white divide remains an important problem we as a nation are facing deep contradictions in how we deal with immigrants and immigration, particularly those coming from Latin America. Historian Martha Biondi muses on continuities with and departures from past traditions in recent discourse surrounding the mission of African American Studies programs and departments.

The epigraphs from Martin Luther King, John Hope Franklin, and Barack Obama at the opening of this essay each, in a fashion, reminds us of the depth and complexity of the matter of race in the U.S. Although it is tempting to seek quick and simple assessments of where we have been and where we are going, it is wise to instead wrestle with taking stock of all the variegated and nuanced circumstances that the black-white divide and associated phenomena involve. Just as 1965 seemed a point of inflection, of contradictory lines of development, future generations may look back and regard 2011 as a similarly fraught moment. At the same time that a nation celebrates the historic election of an African American president, the cultural production of demeaning antiblack images—post cards featuring water melons on the White House lawn prior to the annual Easter egg hunt, the new President featured in loin cloth with a bone through his nose in ads denouncing the health care bill, police officers shooting an out of control chimp under the heading “They'll have to find someone else to write the next stimulus 
bill" - are just a few of the ugly reminders of some of the more overtly racialized reactions to the ascendancy of an African American as president of the United States.

As a result of complex and contradictory indicators, no pithy phrase or bold declaration can possibly do justice to the full body of research, evidence and ideas reviewed here. Certainly one optimistic trend is that examinations of the status of blacks have moved to a place of prominence and sophistication in the social sciences that was probably never even imaged by founding figures of the tradition like W. E. B. Du Bois. That accumulating body of knowledge and theory, including the new contributions herein, deepen our understanding of the experience of race in the U.S. The configuration and salience of the color line some fifty or one hundred years from now, however, cannot be forecast with any measure of certainty. Perhaps the strongest general declaration one can make then at present is that we stand somewhere between a Jim Crow past and the aspiration of a post-racial future. 